\title{
The effect of mitochondrial genome on architectural remodeling and epigenetic reprogramming of donor cell nuclei in mammalian nuclear transfer-derived embryos
}

\author{
M. Samiec \\ National Research Institute of Animal Production, \\ Department of Animal Reproduction Biotechnology \\ 32-083 Balice, Poland
}

(Received 20 April 2004; revised version 5 January 2005; accepted 4 August 2005)

\begin{abstract}
There are some species-specific epigenetic factors present in the oocyte cytoplasm that may contribute to nucleo-cytoplasmic incompatibilities either immediately after nuclear transfer (NT) or at later stages of development. These potential incompatibilities will affect, to some degree, the ultimate utility of NT technology. It has been demonstrated that maternally inherited mitochondrial DNA molecules (mtDNAs) accumulated in the mitochondrial reservoirs of recipient-oocyte cytosol play an important role in nuclear-ooplasmic asynchrony. This asynchrony involves the incompatibility in epigenetic modifications of somatic genome supporting the developmental program of reconstituted cybrids. It also involves incompatibility in molecular mechanisms controlling the karyokinesis and cytokinesis restriction points responsible for coordinated pseudomeiotic to mitotic cycle transition following activation of the reconstituted oocyte. Moreover, the presence of oocyte-derived mitochondrial genetic apparatus influences clonal embryo implantation. For that reason, the deleterious effect on preimplantation development of NT embryos of heterogeneous mtDNA sources arising from possible mitochondrial heteroplasmy in the reconstructed nuclear-cytoplasmic hybrids, should not be discounted. That is why, the production of nuclear transfer embryos, foetuses and offspring with precisely defined constellations of nuclear and/or mitochondrial genome can be valuable for experimentally dissecting the effects of nuclear and cytoplasmic genetic/epigenetic components as well as the intrauterine environment on embryonic, foetal, and postnatal development of cloned individuals.
\end{abstract}

KEY WORDS: mitochondrial DNA, intraspecies cloning, interspecies cloning, nuclear transfer, epigenetic reprogramming, chromatin remodeling

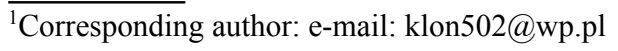




\section{OOCYTE CYTOPLASM-DEPENDENT EPIGENETIC MODIFICATIONS AND NUCLEAR DNA-MITOCHONDRIAL DNA INTERACTIONS IN CLONAL CYTOPLASMIC HYBRIDS (CYBRIDS)}

Intracellular pool of mitochondria and their DNA copy number are connected directly with the stage of cytoplasmic maturity of in vitro cultured recipient oocytes and indirectly with both the nuclear and epigenomic maturational state of maternal DNA. This, in turn, is the genetic marker of the oocyte's ability to functionally reprogramme sperm (in the case of monospermic fertilization) or donor somatic chromatin molecular changes (in the case of cloning by nuclear transfer). It is also a marker of the ability of developing embryos to erase parental genomic imprinting memory arising from epigenetic inheritance (Kono et al., 1996; Latham, 1999; Kikyo and Wolffe, 2000; Smith et al., 2000; Cummins, 2001b; Garesse and Vallejo, 2001; Stojkovic et al., 2001; Surani, 2001; Cecconi, 2002; Mann et al., 2003; St. John et al., 2004). There are some species-specific epigenetic factors present in the oocyte cytoplasm that may contribute to nucleo-cytoplasmic incompatibilities either immediately after nuclear transfer (NT) or at later stages of development (Smith et al., 2000; Cummins, 2001b; Dean et al., 2001; Reik et al., 2001; Rideout III et al., 2001; Shi et al., 2003a; Hiendleder et al., 2004a; Smith and Murphy, 2004; St. John et al., 2004). These potential incompatibilities will affect, to some degree, the ultimate utility of NT technology. It has been demonstrated that maternallyinherited mtDNA molecules accumulated in the mitochondrial reservoirs of the oocyte cytosol play an important role in nuclear-ooplasmic asynchrony. These involve incompatibilities in both the epigenetic modifications of the somatic genome supporting the developmental program of reconstituted cybrids and the molecular mechanisms controlling the karyokinesis and cytokinesis restriction points responsible for coordinatedpseudomeiotic to mitotic cycle transition following activation of the reconstituted oocyte (Nagao et al., 1997; Smith et al., 2000; Garesse and Vallejo, 2001; Surani, 2001; Cezar et al., 2003; Hiendleder et al., 2004a; Smith and Murphy, 2004). Moreover, the presence of oocyte-derived mitochondrial genetic material influences also the clonal embryo implantation (Yamazaki et al., 1999). For that reason, the deleterious effect, on preimplantation development of NT embryos, of heterogeneous mtDNA sources as a result of possible mitochondrial heteroplasmy in the reconstructed nuclear-cytoplasmic hybrids should not be discounted. The regulation of intramitochondrial metabolic processes, as one major cytoplasmic determinant, is complex and involves cooperation of the mitochondrial and the nuclear genomes of actively-dividing clonal embryos (Cummins, 2001a). Hiendleder et al. (1999) reported that up to 95\% of proteins engaged in biogenesis and cytophysiological functions of mitochondria are encoded by the nuclear genome. In addition, it has been shown that more 
than 100 species-specific interactions between proteins encoded by nuclear and mitochondrial DNA, which require tight enzymatic control, are necessary for optimized ATP production (Dey et al., 2000).

CYTOPLASMIC (EXTRANUCLEAR) INHERITANCE AND DIFFERENT PATTERNS OF PARENTAL mIDNA SEGREGATION IN NUCLEARTRANSFERRED EMBRYOS - COMPETITIVENESS OF ONE GENOME OVER ANOTHER (I.E. PREFERENTIAL REPLICATION) OR COEXISTANCE OF OOPLASM-DERIVED AND DONOR CELL mtDNAs (I.E. EPIGENETIC COMPLEMENTATION)

The studies of mitochondrial genome fate in cloned embryos can be helpful to reveal the molecular mechanism of both architectural remodeling of donor nuclear chromatin and epigenetic reprogramming of donor genomic DNA. There have been several reports on the cytoplasmic inheritance of mitochondria and mtDNA following the nuclear transfer technique or oocyte micromanipulation. However, the fate of allogeneic or xenogeneic sources of mitochondrial genome originating from donor cells and recipient cytoplasts (ooplasts) is still controversial and unclear in animals derived from embryos reconstructed by both intraspecies and cross-subspecies as well as interspecies cloning (xenonuclear transplantation of foetal and adult somatic cell nuclei). It has been shown that interspecific nuclear transfer, involving electrofusion of ear skin fibroblasts from sheep, pig, monkey, and rat with enucleated bovine oocytes, result in early development of the clonal embryos, whose cells are all xenomitochondrial cybrids. No pregnancies occurred following transfer into foster mothers (Dominko et al., 1999), indicating that the incompatibility of nuclear DNA- and mitochondrial DNA-encoded components (both transcripts such as mRNA, tRNA, rRNA molecules and protein products) from different species is likely to inhibit normal embryogenesis and foetogenesis. Moreover, Nagao et al. $(1997,1998)$ have demonstrated the deleterious effect of heterogeneous mtDNA copies on in vitro developmental potential of mouse embryos produced by xenonuclear transfer of Mus spretus donor cell nuclei into Mus musculus oocyte cytoplasm. Congenic cloned mice derived from these interspecific NT embryos with mismatch (functional asynchrony) between the nuclear and mitochondrial genome had decreased physical performances. Results of the studies by Nagao et al. (1998) also confirmed that the cytoplast-inherited mtDNA component can be responsible, to a high degree, for non-coordinated nuclear-ooplasmic interactions between maternal transcripts and/or proteins and donor nuclear factors. Together these are defined as genomic discordance between nuclear (donor cell- or karyoplast-mediated) and extranuclear (recipient cell- or 
ooplast-mediated) inheritance in clonal cytoplasmic hybrids. Similarly, mouse xenomitochondrial cybrids harbouring rat mtDNA fractions exhibited reduced metabolic activity, cellular proliferation and frequency of oxidative phosphorylation in heterologous mitochondria, as a result of the genomic incompatibility of nuclearand mitochondrial-encoded products of transcription as well as translation (Dey et al., 2000). Barrientos et al. (2000) reported that mitochondria from gorilla and chimpanzee, but not from the more genetically distant orangutan, were able to restore oxidative phosphorylation in human cells.

Consequences resulting from the transmission of two mitochondrial genomes in interspecies cloned embryos

Interspecies cloning, which involves transferring cell nuclei of one species into enucleated mature oocytes of another species, and then establishing pregnancy in a species other than the nuclear donor, may be the only way to clone and consequently increase the population size of seriously endangered animals or even to restore extinct species. Insufficient oocyte donors and surrogate mothers may make it impractical to produce such threatened species by intraspecies cloning [with the use of allogeneic, autogeneic or isogeneic cell nuclei i.e. originating from the same individual (female) or its monozygotic and monosexual twin, whose oocytes are a source of recipient cells in NT procedure]. Several studies have shown that oocyte cytoplasm from such domesticated animals as 1. cattle (Bos taurus and Bos indicus), 2. sheep (Ovis aries), and 3. cats (Felis silvestris catus) can be used as the universal source of host cytoplasts, which can support embryonic and/or foetal development. This development is regulated by structurally and functionally rearranged foreign chromatin of transplanted somatic cell nuclei from various (susceptible to rapid population collapse) free-living as well as farmed mammalian species. Compatible species are those that are highly phylogenetically related to those above listed and include for 1. gaur (Bos gaurus/B. frontalis; Lanza et al., 2000a; Figure 1) and swamp buffalo (Bubalus bubalis; Nguyen et al., 2000; Kitiyanant et al., 2001; Saikhun et al., 2002); 2. argali (Ovis ammon; White et al., 1999), and mouflon (Ovis orientalis musimon; Loi et al., 2001), and 3. African wild cat (Felis silvestris libica; Gomez et al., 2003, 2004b), respectively. Recent successes in cloning argali (White et al., 1999), gaur (Lanza et al., 2000a; Figure 1), mouflon (Loi et al., 2001) and African wild cats (Gomez et al., 2004a,b) indicate the possibility that the technique of xenonuclear transplantation of somatic cell nuclei to recipient ooplasm of closely related, unthreatened farm or companion animals could be applied to save and, in fact, to reintroduce highly endangered, vanishing or vulnerable wild mammalian species. It has been argued that the full-term development of interspecific clonal cybrids directed by epigenetically reprogrammed 


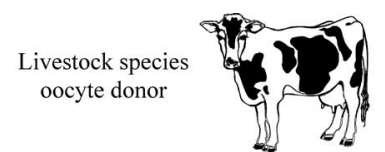

Domestic cow (Bos taurus or Bos indicus)

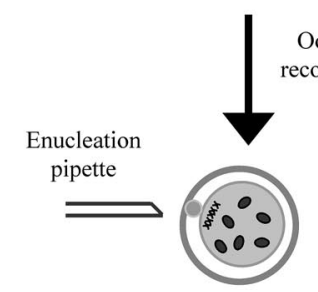

Removal of Metaphase II chromosomes and I polar

body
bomosomes

ody

ocyte

recovering

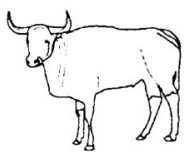

Endangered species somatic cell donor

(female or male)

Gaur (Bos gaurus)

Mitochondria of

recipient oocyte

are marked as

black oval discs.

Establishment of somatic cell lines

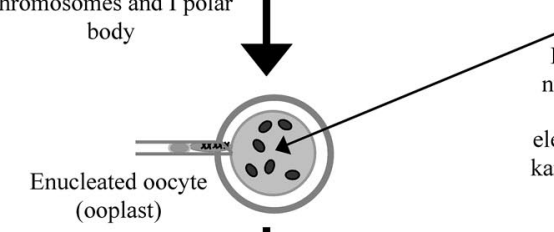

Introduction of somatic cell nucleus into the cytoplasm of

enucleated oocyte (by cell

electrofusion or intraooplasmic

karyoplast/whole cell injection)

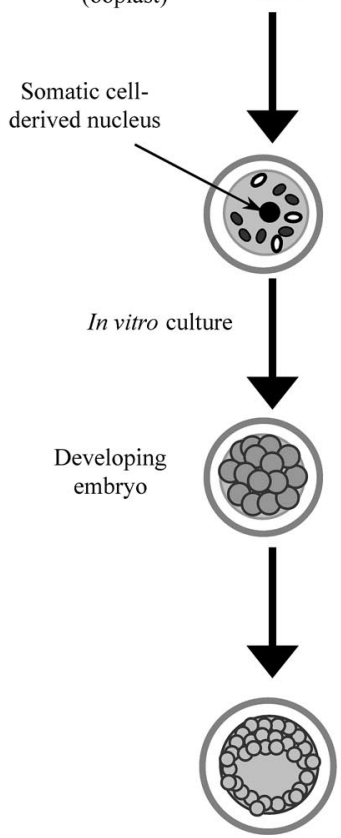

Reconstructed oocyte with donor cell nuclear genome of gaur and mtDNA heteroplasmy (somatic cell mitochondria are marked as white oval discs). After artificial activation, the resultant nuclear-transferred embryo still possesses mitochondria that descended from both species.

The gaur donor cell-derived mitochondria are destroyed during preimplantation stages and the bovine oocyte mtDNA copies are transmitted to the embryonic cells, so mitochondrial genome is inherited maternally or homoplasmically.

Interspecies (hybrid gaurbovine) cloned blastocyst with mtDNA homoplasmy

Figure 1. Schematic diagram of interspecies somatic cloning (xenonuclear transfer of somatic cells), in which nuclear donor cells and recipient oocytes are collected from closely related species. In the preimplanted nuclear transferred embryos, bovine oocyte derived mtDNAs are inherited predominantly/primarily (Lanza et al., 2000a). 
heterologous cell nuclei of gaur (Figure 1), mouflon and African wild cat was achieved, because the NT embryos were homoplasmic for mtDNA molecules as a consequence of predominantly maternal cytoplasmic exchange mechanisms of mitochondria exclusively inherited from recipient oocytes. On the contrary, the studies by Chen et al. $(1999,2002)$ suggest a possible different pattern of mitochondrial transformation in interspecific cloning of giant panda (Ailuropoda melanoleuca) by xenonuclear transfer of abdominal muscle-derived fibroblast cells to cytoplasm of rabbit (Oryctolagus cuniculus) oocytes (Figure 2). By using mitochondrial DNA-specific PCR (polymerase chain reaction) analysis of D-loop regions of panda and rabbit, Chen et al. $(1999,2002)$ indirectly proved that adult somatic cell (SC) nuclei of giant panda are able to dedifferentiate in the ooplasm originating from rabbit. They, therefore, can support early development of the reconstructed embryos by an unique and specific elimination of heteroplasmy phenomenon of the xenogeneic mitochondrial genome. This is induced by the resumption of transcriptional activity by some nuclear DNA genes derived from transplanted panda donor cells. The heterologous sources of mitochondria from both panda somatic cells and rabbit recipient oocytes coexist in clonal embryos at the early blastocyst stage before implantation (Chen et al., 1999, 2002; Figure 2). In contrast, after interspecies uterine implantation of blastocysts, which have developed from panda-rabbit cloned embryos (transferred at the 2- to 4-cell stage, together with hybrid cat-rabbit NT embryos, into the oviducts of domestic cat recipients), mitochondria from donor panda cells remain predominantly "autorenewable" deposits of extranuclearly inherited DNA copies, detectable through PCR analysis of displacement loop segments (Chen et al., 2002). The number of these from rabbit ooplasts is reduced by intracellular ubiquitin ligase complex-dependent biodegradation and/or extrusion into extracellular environment in early xenonuclear-transferred foetuses. A possible interpretation of how these processes limit mtDNA heteroplasmy is that giant pandas and rabbits are genetically further correlated. Thus, selective expression of nuclear genome derived from panda donor cells after maternal to embryonic transition of its control of transcriptional activity leads to biogenesis stimulation of panda cell mitochondria. On the other hand it contributes to inhibiting the autoreplication of mtDNAs and subsequent duplication of mitochondria from rabbit oocytes at G2 stage of cell cycle during foetogenesis. Anyway, this is the only report showing that mitochondria from somatic cells substitute gradually those from enucleated recipient oocytes in interspecies NT embryos. Whether this is a general phenomenon of functional and morphological maturation of genetically-active mitochondria in hybrid clonal embryos, which are reconstructed with donor cell nuclei and recipient oocytes derived from two distantly related species, needs further clarification (Chen et al., 2002). 


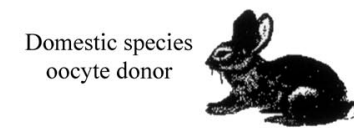

Rabbit (Oryctolagus cuniculus)

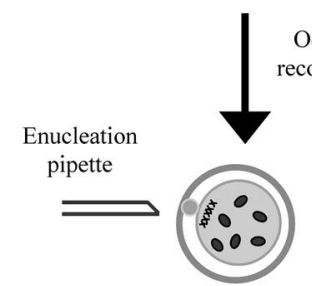

Oocyte recovering

Enucleation pipette
Mitochondria of recipient oocyte are marked as black oval dises.

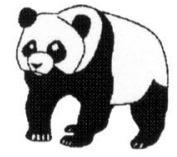

Endangered specie somatic cell donor (female or male)

Giant panda (Ailuropoda melanoleuca)

Establishment of somatic cell lines

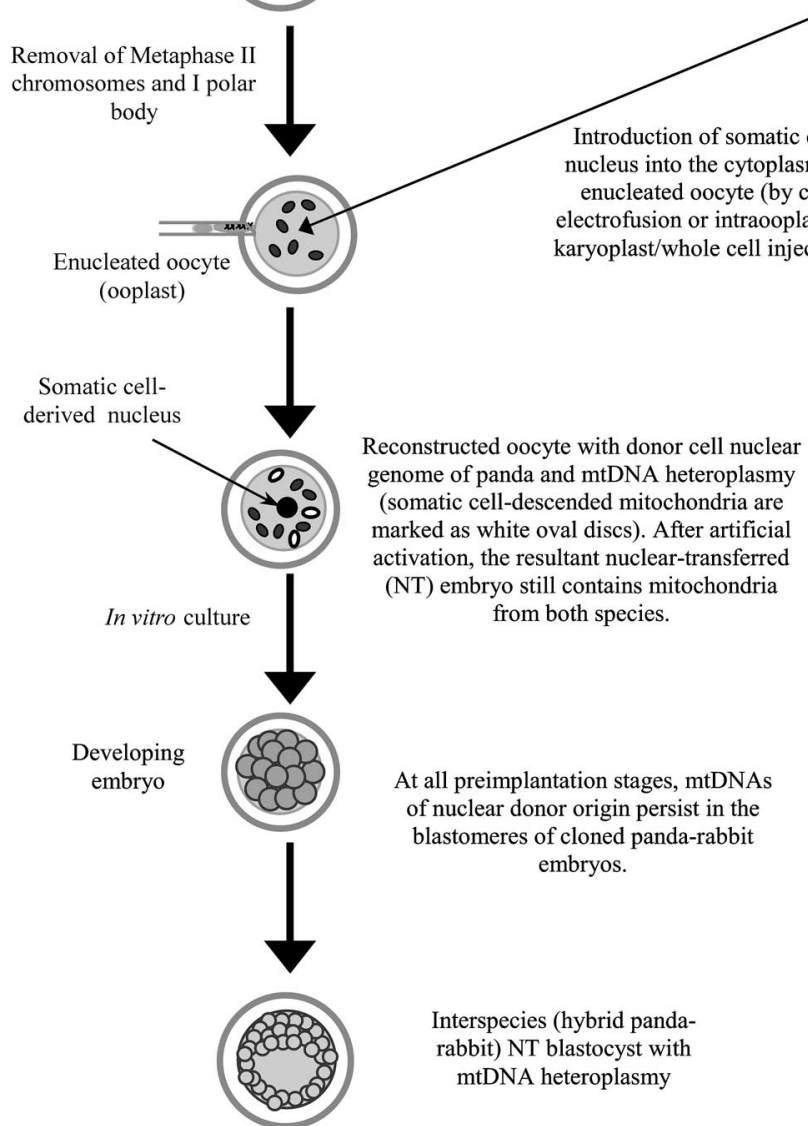

Mitochondria of nuclear donor cells are marked as black rectangles. In turn, black circular plate marks somatic cell nucleus.

Figure 2. Schematic diagram of interspecies somatic cloning (xenonuclear transfer of somatic cells), in which nuclear donor cells and recipient oocytes are collect ed from two distantly related species. In the preimplanted nuclear transferred embryos, mitochondria from donor panda cells and recipient rabbit oocytes coexist (Chen et al., 1999, 2002). 
The results of the studies by Yang et al. $(2003,2004)$ showed that mechanism of distribution of transmitochondrially-descended genetic material in preimplanted xenonuclear-transferred embryos, reconstituted with ear skin-derived fibroblast cells of macaque (Macaca mulatta tcheliensis) and rabbit recipient oocytes, is similar to the pattern of extranuclear inheritance during preimplantation development of the cloned giant panda-rabbit embryos (Chen et al., 1999, 2002). By quantitative analysis of species-specific mtDNA levels using a real-time PCR method, the degrees of mitochondrial genome heteroplasmy (measured with the percentage ratios of macaque mtDNA copy number to rabbit mtDNAs) were estimated in the single hybrid SCNT embryos at seven developmental stages, including 1cell (immediately after cell electrofusion), 2-, 4-, 8- and 16-cell, and morula and blastocyst stages (Yang et al., 2004). It was revealed that the single preimplanted cloned embryos contain $0.54-2.8 \times 10^{4} \mathrm{mtDNA}$ copies of macaque donor cell origin and 0.13-4.7 $\times 10^{7} \mathrm{mtDNA}$ fractions derived from rabbit oocyte cytoplasm. On this basis, it has been demonstrated that both macaque somatic cell- and rabbit ooplasminherited mtDNAs coexist in interspecies cloned embryos at all preimplantation stages, with maternally-transmitted mitochondrial genome being predominant. Similarly, the heteroplasmy of xenogeneic mtDNAs has been identified in macaque-rabbit NT embryos by qualitative analysis using direct PCR product sequencing (Yang et al., 2003). Piko and Taylor (1987) found that in the murine preimplanted embryos there was no mtDNA replication until the blastocyst stage. In the experiments by Yang et al. (2004) it has been shown that in the 1-cell cloned embryos (immediately after reconstruction), the number of mtDNAs from macaque nuclear donor cells was $2.6 \times 10^{4}$, while there were $1.3 \times 10^{6}$ copies of mitochondrial genome from rabbit recipient oocytes. In subsequent in vitro development of hybrid macaque-rabbit SCNT embryos, from the 2-blastomere stage to the morula stage, there were no significant changes in copy numbers of both species-specific mtDNA genotypes. However, at the blastocyst stage, the copy number of macaque somatic cell-derived mtDNA was reduced to $5.4 \times 10^{3}$ while the copy number of maternallyinherited mitotype of rabbit was dramatically increased to the level of $4.7 \times 10^{7}$. Due to the reduction of macaque nuclear donor cell-transmitted mtDNA copies and the increase of recipient cytoplasm-derived mtDNAs, the ratio of somatogenic mtDNA to ooplast-inherited mtDNA also decreased sharply from the level of $2 \%$ in the interspecific SCNT embryos at the 1-cell stage to $0.011 \%$ at the blastocyst stage. These changes in the heteroplasmy degree of xenogeneic mtDNA sources during preimplantation development of cloned macaque-rabbit embryos suggest that the initiation of autoreplicative activity of ooplasmically-descended mitochondrial genome takes place after the morula stage. The results of the studies by Yang et al. (2004) support the conclusion of Piko and Taylor (1987), related to the preimplanted mouse embryos, that the mtDNA replication is induced at the blastocyst stage. 
Consequences resulting from the transmission of two mitochondrial genomes in cross-subspecies cloned embryos

The birth of live and healthy Bos indicus calves produced by nuclear transfer of Bos indicus donor cells (both blastomeres and somatic cells) into Bos taurus recipient cytoplasts proved also that cross-subspecies cloning is a viable approach to rescue or to restore closely related endangered wild and farmed species (Meirelles et al., 2001; Steinborn et al., 2002). Meirelles et al. (2001) demonstrated that the intracytoplasmic fractions of Bos indicus donor cellderived mtDNA were diminished gradually during preimplantation development of clonal hybridic embryos (Figure 3). Thus, somatic mitochondrial genome was completely removed by the end of the gestation through the molecular mechanism of rapid and selective replacement of heterogeneous mitochondrial genotype by maternally or homoplasmically inherited mtDNA haplotype copies. Conversely, Steinborn et al. (2002) found coexisting mtDNAs of both subspecies (Bos indicus and Bos taurus), in born nuclear transfer-derived somatic cattle clones. Both studies indicated that the presence of mitochondrial genome sequences originating from the recipient ooplast or hybridization of mtDNA molecules from maternal (oocytic) inheritance with somatogenic mtDNAs does not inhibit normal development of NT embryos (Meirelles et al., 2001; Steinborn et al., 2002; Figure 3).

Consequences resulting from the transmission of two mitochondrial genomes in intraspecies cloned embryos

Intraspecies cloning usually leads to generation of clonal embryos and resultant offspring in cattle (Steinborn et al., 1998a; Takeda et al., 1999, 2003) and sheep (Evans et al., 1999), whose final composition of parental mitochondrial genome is established during preimplantation development. This is the result of a selective process involving predominant replacement of the exogenous mitochondrial genotype with mitochondrial haplotype of recipient cytoplast origin (Figure 3). Only in some cases does the mitochondria from both donor cells and recipient oocytes coexist in cloned bovine embryos, whose blastomeres are allomitochondrial cybrids from a cytological point of view (Figure 3). That is why calves derived from NT blastocysts transplanted into surrogate mothers, exhibited mtDNA heteroplasmy, induced by both cellular mosaicism of mitochondrial genome sequences and neutral (random) segregation of parental mtDNA haplotypes (the so-called mitotypes) during early embryogenesis (Steinborn et al., 1998b; Hiendleder et al., 1999; Takeda et al., 2003; Figure 3). Recently, Steinborn et al. (2000) reported mitochondrial heteroplasmy in cloned cattle generated from 


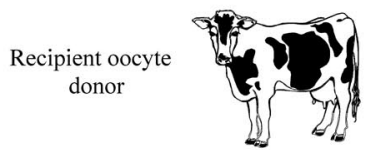

Cattle (Bos taurus or Bos indicus)

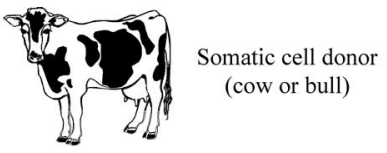

Cattle (Bos taurus or Bos indicus)
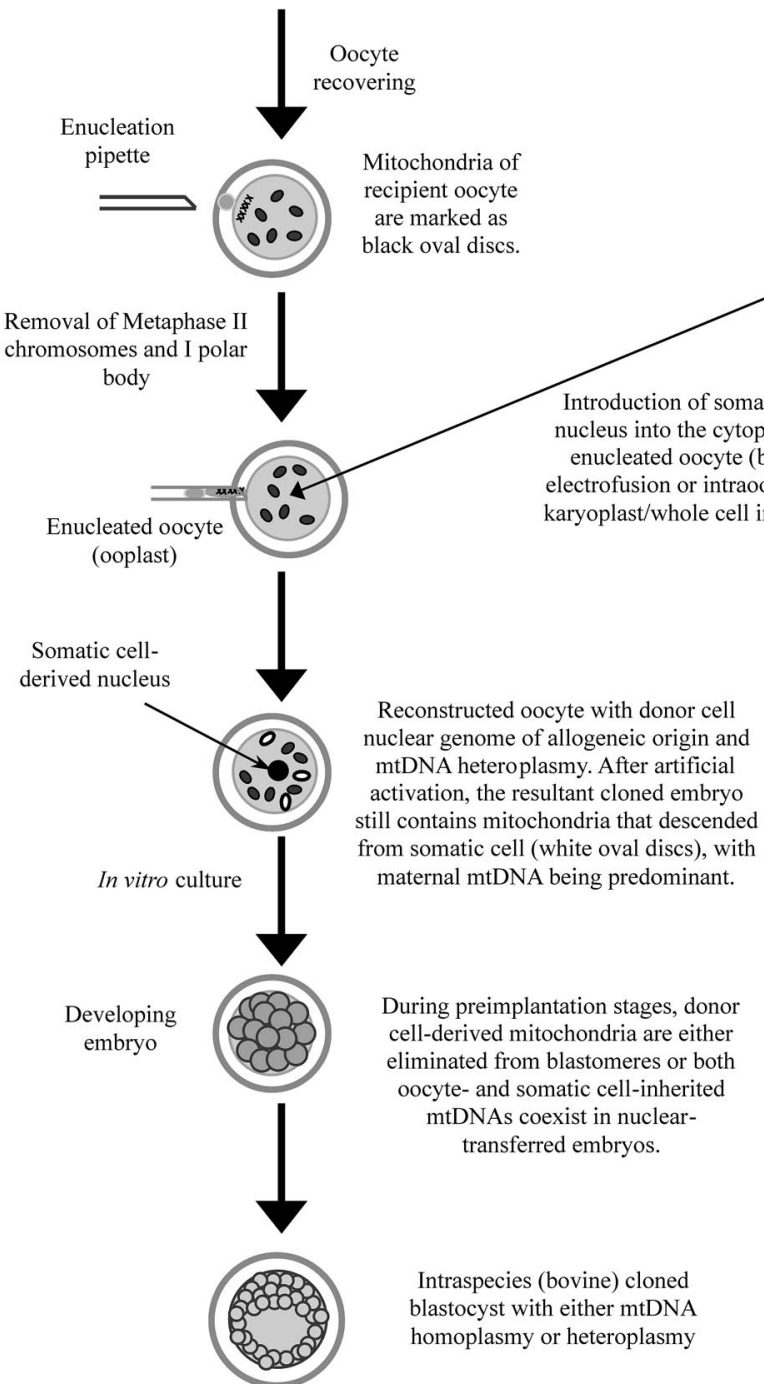

Figure 3. Schematic diagram of intraspecies somatic cloning (nuclear transfer of allogeneic somatic cells). Thus far, the fate of foreign mtDNAs is still controversial in intraspecies cloned embryos. In the bovine nuclear transferred embryos, mitochondrial genome primarily arises from the recipient oocytes (Do et al., 2001; Meirelles et al., 2001), whereas in the others mtDNA copies appear to be heteroplasmic (Steinborn et al., 2000, 2002; Do et al., 2002; Hiendleder et al., 2003; Takeda et al., 2003) 
foetal and adult somatic cells. These authors confirmed that the donor-to-recipient ratios of parental mtDNA molecules remained on the same level throughout embryogenesis and postembryonic development. Interesting results of the studies on fate of mitochondrial genome in clonal bovine embryos during preimplantation development following intraooplasmic microinjection of cumulus cell karyoplasts were achieved also by Do et al. (2002; Figure 3). Mitochondrial DNA heteroplasmy in the NT embryos was analysed by allele-specific PCR (AS-PCR), direct DNA sequencing, and DNA chromatography. AS-PCR analysis for the detection of donor mtDNA fractions was performed at the 1-, 2-, 4-, 8-, 16-cell, morula, and blastocyst stages of in vitro cultured embryos. The mitochondrial genome from nuclear donor cells was detected at all developmental stages of clonal embryos. However, mtDNA heteroplasmy was not ascertained in direct DNA sequencing (and DNA chromatographs) of D-loop control region isolated from NT-derived blastocysts. The cloned blastocysts exhibited only the presence of nucleotide sequences being in accordance with displacement loop segments of recipient oocytes at donorspecific base-pair positions. No regulatory sequence differences were revealed by this analysis method for mitochondrial genotype between recipient cytoplasts and cloned blastocysts. However, if only very small amounts of reaction product are present, any mtDNA sequence differences could remain undetectable. To confirm the mitochondrial heteroplasmy in somatic cell nuclear transfer (SCNT) embryos, the AS-PCR product originating from clonal blastocysts was analysed additionally by DNA sequencing and DNA chromatography. These molecular genetic techniques indicated finally that, in the inner cell mass and trophectoderm cells of nuclear-transferred blastocysts, heterogeneous haplotype copies of cumulus cell-derived mitochondrial genome were inherited together with mtDNA molecules of maternal origin (Figure 3). The results of the studies by Do et al. (2002) suggest that the foreign cytoplasmic (extranuclear) genome from somatic donor cells does not undergo ubiquitin-mediated biodestruction during preimplantation phase of embryogenesis of allomitochondrial clonal cybrids. In addition, it is possible that direct PCR product sequencing and DNA chromatography are methods, which are inappropriate for estimating the mitochondrial heteroplasmy in NT embryos because these analytic techniques are unlikely to be sensitive enough to detect a very small amount of donor cell mtDNA.

The methods for qualitative and/or quantitative analysing the mitochondrial fate in nuclear transfer-derived embryos

Although data concerning the transmission of allogeneic sources of mitochondrial genome after micromanipulation of mammalian embryos are fragmentary and inconsistent, different methods have been used to analyse the 
heteroplasmic inheritance patterns of parental mtDNA copies. These are: 1 . single-strand conformation polymorphism of PCR fragments (PCR-SSCP) in cloned bovine embryos, foetuses and resultant offspring (Takeda et al., 1999, 2003); 2. PCR-mediated restriction fragment length polymorphism (PCR-RFLP) in cloned sheep (Evans et al., 1999) and cloned bovine foetuses (Hiendleder et al., 2004a,b); 3. allele-specific PCR (AS-PCR) in cloned bovine embryos and calves (Steinborn et al., 1998b; Do et al., 2002); 4. direct PCR product sequencing in interspecies cloned panda-rabbit embryos (Chen et al., 2002) and macaquerabbit embryos (Yang et al., 2003), cloned bovine embryos (Do et al., 2002) and ooplasm-transferred humans (Brenner et al., 2000; Barritt et al., 2001); 5. DNA chromatography in cloned bovine embryos (Do et al., 2002) and ooplasmtransferred humans (Brenner et al., 2000; Barritt et al., 2001), and 6. allele-specific real-time PCR in cloned cattle (Steinborn et al., 2000) or real-time (rapid cycle fluorescence monitored) PCR in interspecies cloned macaque-rabbit embryos (Yang et al., 2004). Of these methods, allele-specific PCR is considered to be the most sensitive and suitable technique for the analysis of the mtDNA distribution patterns in the pre- and postimplanted NT-reconstituted embryos. However, all these methods of mtDNA detection can be used to qualify the varying degrees of mitochondrial genome heteroplasmy only, but not to quantify the mtDNA copy number in developing clonal embryos. In the experiments by Yang et al. (2004), real-time quantitative PCR analysis was applied to identify the slight changes of species-specific mtDNA fractions in xenonuclear-transferred macaque-rabbit embryos accurately. It has been shown that this technique can amplify about 10 copies, sometimes even one copy, of macaque or rabbit mtDNA concentration standards. Thus, the real-time PCR method with sensitivity to detect extremely low levels of mitochondrial genome heteroplasmy (less than ten copies of mtDNA) can also be extended to identification of the nuclear genes. Steinborn et al. (2000) quantified the percentage of somatic cell-transmitted mtDNA fractions in cloned bovine embryos and born calves by allele-specific real-time PCR. It was revealed that the ratio of nuclear donor cell-descended mtDNAs to recipient ooplast-inherited mitotypes was approximately $2-5 \%$ (Steinborn et al., 2000) and less than 3-4\% (Takeda et al., 2003) in the reconstructed bovine 1-cell embryos immediately after electrofusion of somatic cell-cytoplast complexes. In the experiments by Steinborn et al. (2000) it was shown that the level of somatogenic mtDNA copies ranged from 0.4 to $4 \%$ and remained the same throughout all the pre- and postimplantation development of bovine nuclear transfer embryos. It was also observed the cellular heteroplasmy of mitochondrial genotype in seven of ten cattle clones with the nuclear donor-to-recipient oocyte ratios ranging from 0.4 to $4 \%$, while the other three clones showed a significant reduction or absence of donor cell-specific mtDNA copies at ratios $\leq 0.3 \%$ (Steinborn et al., 
2000). On the contrary, the studies by Takeda et al. (2003) demonstrated that three $(\mathrm{C} 1, \mathrm{C} 2, \mathrm{C} 3)$ of eleven nuclear-transferred calves/foetuses exhibited the considerably higher degree of mitochondrial genome heteroplasmy $(25-51 \%$, $0-15 \%, 8-59 \%$, respectively in the $\mathrm{C} 1, \mathrm{C} 2, \mathrm{C} 3$ clones) with the differences between tissues observed. Most interesting, however, is a replicative advantage of donor cell-derived mtDNA over the maternally-inherited mtDNA, although it is important to note the differences in the composition of mitotypes (mtDNA haplotypes) between tissues of the same cloned individual (Takeda et al., 2003). This is in contrast to another report where no advantage of somatic cell-mediated mitochondrial genome was found $(0-5 \%$ nuclear donor mtDNA in blood of eighty 12-day bovine NT foetuses; Hiendleder et al., 2003). Moreover, the cells of the cloned foetuses expressed homoplasmic transmission of the recipient ooplasminherited mtDNA copies in all other tissues analysed (skin, muscles, brain, lungs, heart, rumen, jejenum, liver, spleen, kidney and cotyledons; Hiendleder et al., 2003). These variations in the somatogenic mtDNA compositions could be related to differences in the somatic cloning procedure and/or differences in the nuclear-cytoplasmic intergenomic communication in the intraspecies (bovine) NT embryos, foetuses and resultant offspring (Hiendleder et al., 2003; Takeda et al., 2003). The tissue-specific proportion of nuclear donor cell-derived mtDNA fractions in bovine cloned foetuses and calves may also be related to the quantity of somatic cell cytoplasm present in the cybridic clonal embryos post reconstruction/electrofusion (Takeda et al., 2003).

It is beyond any doubt that a great variety of the mtDNA analysis techniques used for NT embryos, foetuses, and offspring is responsible, to a high degree, for discordance or divergence of the results of studies on mitochondrial inheritance in somatic and embryo cloning of mammals. For instance, Do et al. (2002) have demonstrated that donor cell-derived mtDNAs were detectable during preimplantation development of embryos reconstituted by intraooplasmic injection of cumulus cell nuclei (Figure 3). But, this result was contrary to that of their previous experiments (Do et al., 2001), in which the donor mitochondria were eliminated from the cytoplasm of clonal embryo blastomeres between the 8and 16-cell stages of in vitro development (Figure 3). One possible explanation is that somatogenic mitochondria transferred into the cytoplasts may be biodegraded after outer mitochondrial membrane break-down activated by ubiquitin ligase complex, whereas mtDNA molecules released from mitochondrial matrix to cytosol of embryonic cells are transported (imported) and incorporated into the endogenous (maternally inherited) mitochondrial "reservoirs" (King and Attardi, 1988; Gyllensten et al., 1991). From this moment mitochondria, which originate from recipient oocytes, become the carriers of their own genetic information as well as heterogeneous fractions of cytoplasmically inherited genetic material 
or, contrariwise, endogenous mtDNAs from ooplasts are replaced by donor cell mtDNA copies in mitochondrial compartment (King and Attardi, 1989). It is also probable that the molecular signal for mtDNA heteroplasmy detection (MitoTracker Green FM fluorochrome; Molecular Probes Inc., Eugene, OR) disappears at the mitochondrial maturation stage, during which mitochondria undergo extensive ultrastructural transformations (Do et al., 2001). Therefore, further studies are required to determine the mechanism of mitochondrial destruction and the manner of transmission of mtDNA following both SCNT and in vivo as well as in vitro fertilization.

\section{REMODELING/REPROGRAMMING OF DONOR NUCLEAR AND CYTOPLASMIC (OOCYTIC/MATERNAL OR SOMATIC CELL-DERIVED) EPIGENETIC INHERITANCE (METHYLATION STATUS) IN CLONED EMBRYOS}

Successful cloning of animals by NT requires epigenetic reprogramming of the differentiated state of the donor cell nucleus to a totipotent embryonic ground state. It means that the donor nuclei must cease its own program of gene expression and restore a particular program of the embryonic genome expression (transcriptional activity) regulation that is necessary for normal development (Dean et al., 2001; Surani, 2001; Niemann et al., 2002; Shi et al., 2003a). Epigenetic modifications, such as donor genomic DNA methylation and its likely interaction with histone deacetylation and methylation, have been considered to be one of the candidates regulating nuclear reprogramming (Reik et al., 2001; Rideout III et al., 2001; Bortvin et al., 2003; Young and Beaujean, 2004). The most dramatic changes in the DNA methylation level occur throughout the preimplantation development of cloned embryos and during gametogenesis of cloned foetuses (Latham, 1999; Cezar et al., 2003; Santos and Dean, 2004). During early embryonic development, the overall methylation level of the somatic genetic apparatus sharply decreases and reaches a low point at the blastocyst stage. The process of epigenetic reprogramming in early NT embryos erases gamete-specific methylation patterns inherited from the parental genome of nuclear donor cells (Shi et al., 2004; Smith and Murphy, 2004; Young and Beaujean, 2004). This somatic DNA-wide demethylation process may be crucial for the formation of pluripotent stem cells that are important for the later development at the gastrulation stage. During the postimplantation phase of embryogenesis and foetogenesis, a wave of de novo methylation of genetic material takes place and most of the genomic DNA is methylated at defined developmental timepoints (Kang et al., 2001a,b; Reik et al., 2001; Enright et al., 2003; Dindot et al., 2004). Another demethylation/ 
remethylation unique cycle of epigenetic reprogramming occurs throughout the gametogenesis and is necessary for resetting of parental donor genome imprinting (Inoue et al., 2002; Dean et al., 2003; Lee et al., 2003a; Ruddock et al., 2004). Recapitulating, the dynamic, several-step epigenetic modifications of donor genome after somatic cell nuclear transfer (i.e. clonal cybrid reconstruction) include among the other processes of chromatin structure remodeling (Dean et al., 2001; Rideout III et al., 2001; Vignon et al., 2002; Bortvin et al., 2003; Santos and Dean, 2004), global changes in overall DNA methylation status (Kikyo and Wolffe, 2000; Niemann et al., 2002; Archer et al., 2003; Cezar et al., 2003; Shi et al., 2004; Smith and Murphy, 2004; Young and Beaujean, 2004), uniparental (monoallelic) expression of imprinted genes (Latham, 1999; Dean et al., 2003; Mann et al., 2003; Dindot et al., 2004; Ruddock et al., 2004), restoration of telomere length (Tian et al., 2000; Lanza et al., 2000b; Cui et al., 2003; Shi et al., 2003b), and also X chromosome inactivation in female clones (Eggan et al., 2000; Wrenzycki et al., 2002). All these events, which take place synchronously with donor nuclear cycle progression in the cytoplasmic microenvironment of embryonic cells, lead to global rearrangement of the somatic genetic apparatus, at various stages of pre- and postimplantation development (Campbell, 1999a,b; Surani, 2001; Cezar et al., 2003; Enright et al., 2003; Samiec, 2004; Santos and Dean, 2004).

The remodeling and reprogramming of the somatic nuclear apparatus is a result of interaction between factors accumulated in the nucleoplasm and attached to the chromatin, configured in the form of the metaphase plate as a consequence of appropriate rearrangement of its spatial structure and nucleosome repression, with protein factors of recipient cell (oocyte) cytoplasm. This shows that these processes, crucial for mammalian somatic cloning, are not the direct effect of conformance of the exogenous genetic material to cytophysiological conditions of Metaphase II ooplast. This is why the nuclei of somatic cells have a tendency towards minimizing the manifestation degree of developmental programming (Campbell, 1999a; Rideout III et al., 2001; Renard et al., 2002; Shi et al., 2004; Young and Beaujean, 2004). In turn, the low contribution of realizing the somatic genetic program in the preimplantation development of reconstituted embryos should be revealed in conservation through the exogeneic nuclear apparatus of the competence for easy adaptation to the meiotic to mitotic transition of the cell cycle control of activated clonal cybrids (Kono, 1997; Campbell, 1999a,b; Fissore et al., 1999; Vignon et al., 2002; Santos and Dean, 2004). However, the abilities of transplanted cell nuclei to fully direct the developmental program of reconstructed embryos are most likely the result of correct course of molecular mechanisms accompanying both nuclear chromatin remodeling and reprogramming of the somatic cell genome. Proper rearrangement of exogenous genetic apparatus induces only the program 
of active action donor genomic DNA on the hybridic clonal embryo cytoplasm and on the mitochondrial DNA (mtDNA) molecules of heteroplasmic origin and from ooplasmic (maternal) inheritance (Cummins 2001a,b; Garesse and Vallejo, 2001; Brüggerhoff et al., 2002; Dean et al., 2003; Shi et al., 2003a; Hiendleder et al., 2004a; Smith and Murphy, 2004; St. John et al., 2004).

Effect of oocyte reconstruction methods on nuclear and mitochondrial DNA rearrangements in cloned embryos

Nucleoplasmic (karyolymphatic) factors of the somatic cell are engaged directly or indirectly in its structural and functional differentiation. These include transcriptional factors, histones, non-histone HMG (high mobility group) proteins, interacted with transcriptionally-active chromatin, nuclear lamins, polysubunitary protein complexes responsible for remodeling of spatial conformation of chromatin structures and for DNA topology changes (among others nucleosome remodeling factor; NURF, or brahma family proteins: BRG1 and BRM, homological with yeast factors SWI2/SNF2; switch of mating type/sucrose non-fermenting). All of these are associated with nuclear chromatin, and their qualitative and quantitative composition undergo changes in line with progressing cytodifferentiation state. When a whole donor cell is fused with an enucleated oocyte, then those specific factors of the somatic cell are also transferred into the cytoplasm of recipient oocyte and may block an ability of endogenous oocytic factors for appropriate remodeling and reprogramming of foreign (allogenic) cell nucleus (Campbell, 1999b; De Sousa et al., 1999; Rideout III et al., 2001; Loi et al., 2002; Renard et al., 2002; Vignon et al., 2002; Santos and Dean, 2004). Exogenous cytoplasmic factors of the donor cell are incorporated together with proteins and maternal transcripts (mRNA molecules) of oocyte into the remodeled somatic cell nucleus (pseudopronucleus). In turn, a surplus of these hypothetical foreign agents in the ooplasm causes a considerable dilution of specific internal oocyte factors, owing to mutual mingling in the hybridic cytoplasmic environment. This diminishes simultaneously the probability of complete donor nucleus reprogramming (Campbell, 1999a; Fissore et al., 1999; Prather, 2000; Vignon et al., 2002; Shi et al., 2004; Young and Beaujean, 2004). The chief purpose of somatic nucleus intraooplasmic microinjection procedure is to avoid all the above mentioned problems. Introduction of practically only the donor cell nucleus into the cytoplasm of enucleated oocyte increases many times the likelihood of proper action of specific cytosolic oocyte agents on the processes of foreign nuclear chromatin remodeling and genome reprogramming. In this case the only source of exogenous proteins and mRNA transcripts is the nucleoplasm of transplanted karyoplast. Insignificant amounts of perinuclear cytoplasm (perikaryon) remain to interfere with the further embryonic development of mammalian clonal 
zygotes (Lacham-Kaplan et al., 2000; Prather, 2000; Galli et al., 2002; Roh and Hwang, 2002; Lee et al., 2003c; Samiec, 2004; St. John et al., 2004; Yang et al., 2004). Moreover, reducing the volume of allogenic somatic cytoplasm, transplanted into the cytosolic ooplast microenvironment allows for complete avoidance of the limitations caused by heteroplasmic sources of mitochondrial DNA and messenger RNA (including also polycistronic mitochondrial mRNA), originating from somatic donor-cell of nuclear genetic material and from recipient-cytoplast (ooplast). The lack of the impurities in the form of somatic mtDNA in the cytoplasmic environment of the reconstructed oocyte, or the lack of the so-called mtDNA heteroplasmy brings about a consequent decrease in the frequency of the disorders in the epigenetic reprogramming of nuclear DNA and mitochondrial DNA (in consequence of hypermethylation or excessive demethylation of DNA cytosine residues; Garesse and Vallejo, 2001; Reik et al., 2001; Surani, 2001; Roh and Hwang, 2002; Gomez et al., 2003; Smith and Murphy, 2004). All disturbances in dynamic homeostasis of epigenetic modifications of somatic cell genome may result from asynchronous structural remodeling of nuclear chromatin (non-coordinated deacetylation/ acetylation of histones and elevation of nucleosomal repression level through decrease of SWI2/SNF2 protein complex activity), as well as asynchronous changes of spatial configuration of regulatory D-loop of "naked", circular mtDNA molecules of nuclear-transferred embryos (Santos and Dean, 2004; Hiendleder et al., 2004a; St. John et al., 2004). The maintenance of correct DNA methylation pattern in the nuclei of all descendant blastomeres of preimplantational clonal embryos favours also the preservation, in the intact form, of the mechanisms responsible for parental genome imprinting (uniparental/monoallelic gene expression). In turn, this is reflected in flawless rearrangement of exogenous chromatin as well as reprogramming of nuclear and mitochondrial genetic apparatus, and, in extreme cases, even in partial remodeling of chromatin structures. It thus avoids the inhibition of transcriptional activity of the larger part of embryonic genome in the early stages of embryogenesis (Latham, 1999; Smith et al., 2000; Cummins, 2001a,b; Dean et al., 2001; Niemann et al., 2002; Renard et al., 2002; Mann et al., 2003; Yang et al., 2004).

CREATION (RECONSTRUCTION) OF HOMOPLASMIC CLONAL CYBRIDS BY THE FUSION OF ENUCLEATED OOCYTES (CYTOPLASTS) WITH mtDNA-DEPLETED CELLS POSSESSING SOMATIC NUCLEI

A truly groundbreaking solution, enabling total elimination or at least considerable diminution of mtDNA heteroplasmy in the somatic cell nuclear transfer (SCNT) embryos reconstructed by cell electrofusion or whole cell intraooplasmic microinjection, turned out to be the use of cell donors depleted 
of mtDNA molecules. It allows the production of cloned embryos homoplasmic for mtDNAs (Lee et al., 2003b). Lee et al. compared the in vitro developmental potential of ovine embryos reconstituted with cell nuclei of primary foetal fibroblasts and mtDNA-depleted foetal fibroblasts as donor cells. Ovine fibroblast cells were cultured without serum deprivation and used as a nuclear donor source at $60-70 \%$ confluency state. Donor cells were depleted of mtDNA by treatment with low concentration $(50 \mathrm{ng} / \mathrm{mL})$ of ethidium bromide (EB), a known inhibitor of mtDNA replication. Incubation of fibroblast cells in culture medium with addition of ethidium bromide promotes the production of homogenous cell population deprived of mitochondrial genome. It also promotes a relatively high degree of synchronization of competitive inhibition of enzymatic systems of mtDNA autoreplication, thereby minimizing mtDNA copies per mitochondrion and per cell in all the treated cell population. The proportion of fused somatic cell-ooplast couplets was significantly greater in the control group than with EB-treated cells (87 vs $73 \%$ ). In addition the cleavage rate of control fused embryos was significantly higher than that of embryos obtained using mtDNA-depleted cells (81 vs 59\%). However, no significant difference was observed in blastocyst formation rate (32 vs $23 \%$, respectively) or total blastocyst cell number (approximately 94 vs 74 cells) on day 7 of in vitro culture. In turn, Lloyd et al. (2003) confirmed repeatability of the results of the study by Lee et al. (2003b) using caprine, ovine and bovine foetal fibroblast primary cell cultures for depletion of mtDNA molecules. These somatic cells of all farm ruminant animal species were produced to eliminate the possible transmission of donor cell mitochondrial genome at the SCNT stage, but the aim of these investigations was to determine whether mitochondrial mRNA molecules persist following mtDNA depletion. During the chemically induced removal process of mtDNAs, treated somatic cells were collected and then the expression of several mitochondrial genes encoding proteins of the respiratory chain, including three subunits of NADH dehydrogenase $(N D 1, N D 2, N D 3)$ and one subunit of cytochrome C oxidase (COXII), was analysed by reverse transcription-PCR (RT$\mathrm{PCR}$ ). Detection of concentration levels of mtDNA transcripts in different species donor cells by RT-PCR analysis revealed either a sequential decrease to trace concentrations or an absence of mitochondrial mRNA fraction for all the abovementioned mitochondrial genes, which effectively incorporated ethidium bromide. Elimination of both the donor cell mtDNA molecules and mitochondrial transcripts, prior to nuclear transfer to the enucleated recipient oocyte, should facilitate the architectural remodeling. It should also facilitate epigenetic reprogramming of the somatic cell nucleus in clonal cybrids, allowing for correct regulation of maternal (oocytic) mtDNA autoreplication and transcription by this spatially rearranged and epigenetically modified genetic apparatus, as a result of only homoplasmic sequence variants of the control D-loop region. 
EFFECT OF MATERNAL LINEAGE OF RECIPIENT OOCYTES ON THE EXTRANUCLEAR GENETIC/EPIGENETIC INHERITANCE AND NUCLEOCYTOPLASMIC INTERACTIONS IN CLONED EMBRYOS

Recently, Brüggerhoff et al. (2002) have shown that maternal lineage of recipient oocytes has a significant effect on the proportion of bovine NT embryos developing to transferable morulae and blastocysts, which provides experimental evidence for the influence of ooplast cytosolic components on the efficiency of somatic cloning in cattle. In utero developmental capacity of transferred bovine cloned embryos is also significantly affected by the type of recipient oocyte cytoplasm (Hiendleder et al., 2004a). This genetically-controlled phenomenon has not been described so far, probably because, in most studies on bovine nuclear transfer, a large number of oocytes with non-defined mtDNA genotypes are recovered from the ovaries of slaughtered cows or heifers to enable a strong selection for high-quality oocytes. Thus, varying compatibility between nuclear and cytoplasmically inherited mitochondrial genes in cloned calves has been discussed as a potential reason for the wide variation in body weight of these specients (Gärtner et al., 1998). To address this point, Brüggerhoff et al. (2002) combined SCNT and ultrasound-guided ovarian follicle aspiration (ovum pick-up [OPU]) technology for the production of clonal embryos with defined nuclear DNA and mitochondrial DNA constellations. Two maternal lineages of oocyte donors of the same breed (Simmental cattle) were selected according to a relatively large divergence of their Bos taurus mitochondrial genome sequences. Overall, 11 variable nucleotide positions were found in control regions (CRs) in mtDNA of both lineages. These consist of 4 insertions/deletions and 7 transitions. At least two segments of mutageneic polymorphism of nucleotide sequences detected in the mtDNA copies of the examined maternal lineages are located in important domains of the D-loop control region, which are believed to be critical for regulating the function of mitochondrial genome. One purine to pyrimidine base $(\mathrm{C} / \mathrm{T})$ substitution was located in CSB 1, a conserved sequence block with significant mtTFA (mitochondrial transcription factor A) binding, a regulatory element involved in the initiation of heavy-strand DNA synthesis. The CSB 1 is believed to signal the transition from transcription to autoreplication of mtDNA. A single nucleotide (C) deletion was observed in CSB 2+3, another conserved element involved in mtDNA transcription and replication (Ghivizzani et al., 1993, 1994). Two additional polymorphic sequences resulting from A/G substitutions were found in the vicinity of the heavy-strand origin of replication $\left(\mathrm{O}_{\mathrm{H}}\right.$; King and Low, 1987). Thus, the investigated sequence differences between the two mtDNA genotypes (haplotypes) of oocyte donors could account for the importance of maternal lineage effects in both interactions between nuclear and ooplasmic factors (among others; proteins, DNA transcripts such as mRNA, 
rRNA, tRNA molecules) in SCNT embryos. They could also account for genomic incompatibilities between somatogenic mtDNA- and recipient cytoplast-derived mtDNA-encoded gene expression products as well as in the genotypic discordance between donor cell nuclear genetic apparatus and ooplasmically inherited mtDNA molecules (Brüggerhoff et al., 2002; Hiendleder et al., 2004a).

INDUCTION OF MITOCHONDRIAL HETEROPLASMY IN CLONED EMBRYOS/FOETUSES NOT ONLY BY DIFFERENT SEGREGATION PATTERNS OF NUCLEAR DONOR mtDNAs BUT ALSO BY THE TRANSMISSION (TRANSPLACENTAL LEAKAGE) OF SURROGATE FEMALE MITOCHONDRIA INTO FOETAL BLOOD

Besides the differences in mtDNA haplotypes (i.e. mitotypes), different species-specific and even age-related directional segregation patterns (random/ neutral or selective/non-neutral, i.e. the so-called tissue-specific selection) of maternally inherited and donor cell-derived mtDNAs (Jenuth et al., 1997; Meirelles and Smith, 1998; Takeda et al., 2000; Meirelles et al., 2001; Hiendleder et al., 2003, 2004a) have to be considered as factors limiting the in vitro and in vivo developmental competences of clonal embryos. So too do different heteroplasmic ratios of endo- and exogenous mtDNA copies (Steinborn et al., 1998b; Hiendleder et al., 1999) or general preferential replication of nuclear donor mtDNA (i.e. replicative advantage of one mtDNA genotype; Meirelles and Smith, 1997) as well as the intrauterine environment of foster mothers (Plante et al., 1992). One of the most interesting findings of the study by Hiendleder et al. (2003) is the detection of mitochondrial genome copies of surrogate heifers in DNA samples extracted from blood of two cloned bovine foetuses (both singletons), pointing to leakage of the placental barrier and mimicking mitochondrial heteroplasmy. This might be even more common, because in these experiments, mtDNA genotype combinations of only three transmitochondrial clonal foetuses and recipient heifers would have enabled detection of this phenomenon. Confirmation of this hypothesis are the results of the second series of experiments by Hiendleder et al. (2004b). They have investigated the possible exchange of genetic material between SCNT-derived bovine foetuses and recipient females at day 80 of gestation using the high copy number of mitochondrial genome as a marker. Twenty three recovered cloned foetuses and their foster mothers were screened for divergent mtDNA combinations in haematocytes of cardiovascular system. Only such heterogeneous fractions of cytoplasmic genetic apparatus in nucleartransferred allomitochondrial foetuses (i.e. expressing tissue-specific mtDNA heteroplasmy) are informative for the detection of a second mtDNA haplotype 
that could provide evidence for the presence of transplacentally leaked whole cells or cell components of recipient surrogates. By using PCR-RFLP method for the detection of mitochondrial genotype heteroplasmy it was found the presence of a total of five allogeneic mitochondrial haplotypes among cloned foetuses and their recipient surrogates. Three of these mitotypes were predicted to occur in a subset of the cloned foetuses based on the known mtDNA genotype of oocyte donor females (subjected to ovum pick-up treatments). Another haplotype was identical to the nuclear donor cell (i.e. mural granulosa cell)-inherited mtDNA haplotype and occurred at a relatively high frequency $(26.2 \%)$ among the recipient cattle and foetuses originating from SCNT embryos reconstructed with oocytes, which had been randomly collected from slaughterhouse ovaries. An apparently rare mitotype occurred only once in a foetus derived from nuclear-transferred embryo reconstituted with enucleated abattoir oocyte.

A search for recipient female-descended mtDNA haplotype in DNA extracts from foetal blood by the PCR-RFLP analysis revealed two cases of mtDNA heteroplasmy (i.e. presence of foster mother-derived mitotype) among a total of eight informative foetus-recipient pairs (Hiendleder et al., 2004b). Maternal-foetal chimerism, which was probably induced not only in haematocytes of the blood circulation but also in haemocytoblasts of the haematopoietic system of the two SCNT foetuses, was related to the recipient mtDNA haplotype that differed from the nuclear donor cell mitotype. A comparison of band intensities in chimeric blood samples with artificially mixed samples yielded estimates for the surrogate femalederived mitochondrial genotype proportion of approximately 2.5 to $5 \%$. In turn, among the four sets of recovered twin cloned foetuses, only one set had a divergent mtDNA haplotype. One of the nuclear-transferred twins showed a mitotype identical to the foster mother while the other twin had the mitochondrial genotype identical to the nuclear donor cell. The analysis of DNA extracts of the two SCNT foetuses revealed massive mitochondrial genome-related chimerism in foetal blood. Further analyses on nine different tissue explants, which were isolated from heart, kidneys, lungs, stomach, liver, brain, muscles, cotyledons and small intestine of twin cloned foetuses, provided evidence for the minor maternal-foetal chimerism in mtDNA samples derived from the liver tissue of one of these foetuses (Hiendleder et al., 2004b).

Placental abnormalities that could cause leakage of blood cells have recently been reported in cloned mammals, including improper vascular development and haemorrhagic cotyledons (Hill et al., 2000; De Sousa et al., 2001; ChavattePalmer et al., 2002; Heyman et al., 2002). Heteroplasmy derived from the foster mothers could explain the unexpected mtDNA genotypes detected in three allomitochondrial (exhibiting heterogeneity of cytoplasmic genetic apparatus fractions) cloned calves produced as a result of previous investigation (Takeda et 
al., 1999), in which the nuclear donor cell mtDNA genotype was known but did not match the second mtDNA genotype in the calves. Two of these NT-derived calves were from the same pregnancy and showed exactly the same single strand conformation polymorphism (SSCP) band patterns (Takeda et al., 1999). It is common practice to transfer more than one reconstructed embryo at blastocyst stage to recipient surrogates in cattle (Cibelli et al., 1998; Wells et al., 1999). Some of the previously revealed heteroplasmy phenomena in DNA samples isolated from blood of nuclear-transferred specients (Steinborn et al., 1998b; Hiendleder et al., 1999; Takeda et al., 1999) could therefore actually have been caused by leukocyte/ lymphocyte or erythroblast chimerism in haematopoietic system because of fusion of the chorioallantois and placental vascular anastomoses, which is encountered in more than $90 \%$ of calves originating from multiple births (Bishop, 1972; PessaMorikawa et al., 2004).

\section{CONCLUSIONS}

Production of nuclear transfer embryos, foetuses and offspring with exactly defined constellations of nuclear and/or mitochondrial genome can be a valuable tool to experimentally dissect the effects of nuclear and cytoplasmic genetic and/or epigenetic components as well as intrauterine environment of recipient surrogates on embryonic, foetal, and postnatal development of cloned individuals (Plante et al., 1992). Significant contributions of cytoplasmically inherited mtDNA genotype to variation in several postnatal quantitative traits of economic importance, such as milk fat yield (Schutz et al., 1992, 1994), reproductive performance (fertility; Starno et al., 2002) and carcass composition (Mannen et al., 1998), have already been detected by genetic analysis of quantitative trait loci (QTLs). Experimental confirmation of these findings requires generation of cloned farm animals with defined constellations of nuclear and mitochondrial DNA. Recently, cloned transgenic livestock have been produced by nuclear transfer of in vitro transfected somatic cells (Cibelli et al., 1998; McCreath et al., 2000; Keefer et al., 2001; Park et al., 2002; Bordignon et al., 2003). When, e.g., a transgenic line of animal bioreactors synthesizing human recombinant proteins (biopharmaceuticals) in mammary gland and providing them with the milk is established by NT, inheritance of parental mtDNA molecules can be important because some proteins encoded by genes, which are located in the mitochondrial genome, can affect the quantitative level/state of expression of certain phenotype traits such as milk production in cattle (Schutz et al., 1994). 


\section{REFERENCES}

Archer G.S., Dindot S., Friend T.H., Walker S., Zaunbrecher G., Lawhorn B., Piedrahita J.A., 2003. Hierarchical phenotypic and epigenetic variation in cloned swine. Biol. Reprod. 69, 430-436

Barrientos A., Muller S., Dey R., Wienberg J., Moraes C.T., 2000. Cytochrome c oxidase assembly in primates is sensitive to small evolutionary variations in amino acid sequence. Mol. Biol. Evol. $17,1508-1519$

Barritt J.A., Brenner C.A., Malter H.E., Cohen J., 2001. Mitochondria in human offspring derived from ooplasmic transplantation. Hum. Reprod. 16, 513-516

Bishop M.W.H., 1972. Genetically determined abnormalities of the reproductive system. J. Reprod. Fertil. 15, Suppl., 51-69

Bordignon V., Keyston R., Lazaris A., Bilodeau A.S., Pontes J.H.F., Arnold D., Fecteau G., Keefer C., Smith L.C., 2003. Transgene expression of green fluorescent protein and germ line transmission in cloned calves derived from in vitro-transfected somatic cells. Biol. Reprod. 68, 2013-2023

Bortvin A., Eggan K., Skaletsky H., Akutsu H., Berry D.L., Yanagimachi R., Page D.C., Jaenisch R., 2003. Incomplete reactivation of Oct4-related genes in mouse embryos cloned from somatic nuclei. Development 130, 1673-1680

Brenner C.A., Barritt J.A., Willadsen S., Cohen J., 2000. Mitochondrial DNA heteroplasmy after human ooplasmic transplantation. Fertil. Steril. 74, 573-578

Brüggerhoff K., Zakhartchenko V., Wenigerkind H., Reichenbach H.-D., Prelle K., Scernthaner W., Alberio R., Kuchenhoff H., Stojkovic M., Brem G., Hiendleder S., Wolf E., 2002. Bovine somatic cell nuclear transfer using recipient oocytes recovered by ovum pick-up: effect of maternal lineage of oocyte donors. Biol. Reprod. 66, 367-373

Campbell K.H.S., 1999a. Nuclear transfer in farm animal species. Cell Dev. Biol. 10, 245-252

Campbell K.H.S., 1999b. Nuclear equivalence, nuclear transfer, and the cell cycle. Cloning 1, 3-15

Cecconi S., 2002. Growth and differentiation of small ovarian follicles in mammals: problems and future perspectives. J. Reprod. Develop. 48, 431-445

Cezar G.G., Bartolomei M.S., Forsberg E.J., First N.L., Bishop M.D., Eilertsen K.J., 2003. Genomewide epigenetic alterations in cloned bovine foetuses. Biol. Reprod. 68, 1009-1014

Chavatte-Palmer P., Heyman Y., Richard C., Monget P., LeBourhis D., Kann G., Chilliard Y., Vignon X., Renard J.P., 2002. Clinical, hormonal, and hematologic characteristics of bovine calves derived from nuclei from somatic cells. Biol. Reprod. 66, 1596-1603

Chen D.-Y., Sun Q.-Y., Liu J.-L., Li G.-P., Lian L., Wang M.-K., Han Z.-M., Song X.-F., Li J.-S., Sun Q., Chen Y.-C., Zhang Y.-P., Ding B., 1999. The giant panda (Ailuropoda melanoleuca) somatic nucleus can dedifferentiate in rabbit ooplasm and support early development of the reconstructed egg. Sci. China, Ser. C, 29, 324-330

Chen D.-Y., Wen D.-C., Zhang Y.-P., Sun Q.-Y., Han Z.-M., Liu Z.-H., Shi P., Li J.-S., Xiangyu J.-G., Lian L., Kou Z.-H., Wu Y.-Q., Chen Y.-C., Wang P.-Y., Zhang H.-M., 2002. Interspecies implantation and mitochondria fate of panda-rabbit cloned embryos. Biol. Reprod. 67, 637-642

Cibelli J.B., Stice S.L., Goluece P.J., Kane J.J., Jerry J., Blackwell C., Ponce de Leon F.A., Robl J.M., 1998. Cloned transgenic calves produced from nonquiescent fetal fibroblasts. Science 280, 1256-1258

Cui W., Wylie D., Aslam S., Dinnyes A., King T., Wilmut I., Clark A.J., 2003. Telomeraseimmortalized sheep fibroblasts can be reprogrammed by nuclear transfer to undergo early development. Biol. Reprod. 69, 15-21

Cummins J.M., 2001a. Mitochondria: potential roles in embryogenesis and nucleocytoplasmic transfer. Hum. Reprod. 7, 217-228 
Cummins J.M., 2001b. Cytoplasmic inheritance and its implications for animal biotechnology. Theriogenology 55, 1381-1399

Dean W., Santos F., Reik W., 2003. Epigenetic reprogramming in early mammalian development and following somatic nuclear transfer. Semin. Cell Dev. Biol. 14, 93-100

Dean W., Santos F., Stojkovic M., Zakhartchenko V., Walter J., Wolf E., Reik W., 2001. Conservation of methylation reprogramming in mammalian development: aberrant reprogramming in cloned embryos. Proc. Nat. Acad. Sci. USA 98, 13734-13738

De Sousa P.A., King T., Harkness L., Young L.E., Walker S.K., Wilmut I., 2001. Evaluation of gestational deficiencies in cloned sheep fetuses and placentae. Biol. Reprod. 65, 23-30

De Sousa P.A., Winger Q., Hill J.R., Jones K., Watson A., Westhusin M.E., 1999. Reprogramming of fibroblast nuclei after transfer into bovine oocytes. Cloning 1, 63-69

Dey R., Barrientos A., Moraes C.T., 2000. Functional constraints of nuclear-mitochondrial DNA interactions in xenomitochondrial rodent cell lines. J. Biol. Chem. 275, 31520-31527

Dindot S.V., Farin P.W., Farin C.E., Romano J., Walker S., Long C., Piedrahita J.A., 2004. Epigenetic and genomic imprinting analysis in nuclear transfer derived Bos gaurus/Bos taurus hybrid fetuses. Biol. Reprod. 71, 470-478

Do J.T., Hong K.H., Lee B.Y., Kim S.B., Kim N.H., Lee H.T., Chung K.S., 2001. In vitro development of reconstructed bovine embryos and fate of donor mitochondria following nuclear injection of cumulus cells. Zygote 9, 211-218

Do J.T., Lee J.W., Lee B.Y., Kim S.B., Ryoo Z.Y., Lee H.T., Chung K.S., 2002. Fate of donor mitochondrial DNA in cloned bovine embryos produced by microinjection of cumulus cells. Biol. Reprod. 67, 555-560

Dominko T., Mitalipova M., Haley B., Beyhan Z., Memili E., McKusick B., First N.L., 1999. Bovine oocyte cytoplasm supports development of embryos produced by nuclear transfer of somatic cell nuclei from various mammalian species. Biol. Reprod. 60, 1496-1502

Eggan K., Akutsu H., Hochedlinger K., Rideout III W., Yanagimachi R., Jaenisch R., 2000. Xchromosome inactivation in cloned mouse embryos. Science 290, 1578-1581

Enright B.P., Kubota C., Yang X., Tian X.C., 2003. Epigenetic characteristics and development of embryos cloned from donor cells treated by trichostatin A or 5-aza-2'-deoxycytidine. Biol. Reprod. 69, 896-901

Evans M.J., Gurer C., Loike J.D., Wilmut I., Schnieke A.E., Schon E.A., 1999. Mitochondrial DNA genotypes in nuclear transfer-derived cloned sheep. Nat. Genet. 23, 90-93

Fissore, R.A., Long, Ch.R., Duncan, R.P., Robl, J.M., 1999. Initiation and organization of events during the first cell cycle in mammals: applications in cloning. Cloning 1, 89-100

Galli C., Lagutina I., Vassiliev I., Duchi R., Lazzari G., 2002. Comparison of microinjection (piezoelectric) and cell fusion for nuclear transfer success with different cell types in cattle. Cloning Stem Cells 4, 189-196

Garesse R., Vallejo C.G., 2001. Animal mitochondrial biogenesis and function: a regulatory crosstalk between two genomes. Gene 263, 1-16

Gärtner K., Bondioli K., Hill K., Rapp K., 1998. High variability of body sizes within nucleustransfer-clones of calves - artifacts or a biological feature? Reprod. Domest. Anim. 33, 67-75

Ghivizzani S.C., Madsen C.S., Hauswirth W.W., 1993. In organello footprinting. Analysis of protein binding at regulatory regions in bovine mitochondrial DNA. J. Biol. Chem. 268, 8675-8682

Ghivizzani S.C., Madsen C.S., Nelen M.R., Ammini C.V., Hauswirth W.W., 1994. In organello footprint analysis of human mitochondrial DNA: human mitochondrial transcription factor A interactions at the origin of replication. Mol. Cell Biol. 14, 7717-7730

Gomez M.C., Jenkins J.A., Giraldo A., Harris R.F., King A., Dresser B.L., Earle Pope C., 2003. Nuclear transfer of synchronized African wild cat somatic cells into enucleated domestic cat oocytes. Biol. Reprod. 69, 1032-1041 
Gomez M.C., Pope C.E., Giraldo A.M., Lyons L., Harris R.F., King A., Cole A., Godke R.A., Dresser B.L., 2004a. Birth of African wild cat cloned kittens. Reprod. Fertil. Dev. 16, International Embryo Transfer Society (IETS), 141 (Abstr.)

Gomez M.C., Pope C.E., Giraldo A., Lyons L.A., Harris R.F., King A.L., Cole A., Godke R.A., Dresser B.L., 2004b. Birth of African Wildcat cloned kittens born from domestic cats. Cloning Stem Cells 6, 247-258

Gyllensten U., Wharton D., Josefsson A., Wilson A.C., 1991. Paternal inheritance of mitochondrial DNA in mice. Nature 352, 255-257

Heyman Y., Chavatte-Palmer P., LeBourhis D., Camous S., Vignon X., Renard J.P., 2002. Frequency and occurrence of late-gestation losses from cattle cloned embryos. Biol. Reprod. 66, 6-13

Hiendleder S., Bebbere D., Zakhartchenko V., Reichenbach H.-D., Wenigerkind H., Ledda S., Wolf E., 2004b. Maternal-fetal transplacental leakage of mitochondrial DNA in bovine nuclear transfer pregnancies: potential implications for offspring and recipients. Cloning Stem Cells 6, 150-156

Hiendleder S., Prelle K., Brüggerhoff K., Reichenbach H.-D., Wenigerkind H., Bebbere D., Stojkovic M., Müller S., Brem G., Zakhartchenko V., Wolf E., 2004a. Nuclear-cytoplasmic interactions affect in utero developmental capacity, phenotype, and cellular metabolism of bovine nuclear transfer fetuses. Biol. Reprod. 70, 1196-1205

Hiendleder S., Schmutz S.M., Erhardt G., Green R.D., Plante Y., 1999. Transmitochondrial differences and varying levels of heteroplasmy in nuclear transfer cloned cattle. Mol. Reprod. Dev. 54, 24-31

Hiendleder S., Zakhartchenko V., Wenigerkind H., Reichenbach H.-D., Brüggerhoff K., Prelle K., Brem G., Stojkovic M., Wolf E., 2003. Heteroplasmy in bovine fetuses produced by intra- and inter-subspecific somatic cell nuclear transfer: neutral segregation of nuclear donor mitochondrial DNA in various tissues and evidence for recipient cow mitochondria in fetal blood. Biol. Reprod. 68, 159-166

Hill J.R., Burghardt R.C., Jones K., Long C.R., Looney C.R., Shin T., Spencer T.E., Thompson J.A., Winger Q.A., Westhusin M.E., 2000. Evidence for placental abnormalities as the major cause of mortality in first-trimester somatic cell cloned bovine fetuses. Biol. Reprod. 63, 1787-1794

Inoue K., Kohda T., Lee J., Ogonuki N., Mochida K., Noguchi Y., Tanemura K., Kaneko-Ishino T., Ishino F., Ogura A., 2002. Faithful expression of imprinted genes in cloned mice. Science 295, 297

Jenuth J.P., Peterson C.A., Shoubridge E.A., 1997. Tissue specific selection for different mtDNA genotypes in heteroplasmic mice. Nat. Genet. 16, 93-95

Kang Y.-K., Koo D.-B., Park J.-S., Choi Y.-H., Chung A.-S., Lee K.-K., Han Y.-M., 2001a. Aberrant methylation of donor genome in cloned bovine embryos. Nat. Genet. 28, 173-177

Kang Y.-K., Koo D.-B., Park J.-S., Choi Y.-H., Kim H.-N., Chang W.-K., Lee K.-K., Han Y.-M., 2001b. Typical demethylation events in cloned pig embryos. Clues on species-specific differences in epigenetic reprogramming of a cloned donor genome. J. Biol. Chem. 276, 39980-39984

Keefer C.L., Baldassarre H., Keyston R., Wang B., Bhatia B., Bilodeau A.S., Zhou J.F., Leduc M., Downey B.R., Lazaris A., Karatzas C.N., 2001. Generation of dwarf goat (Capra hircus) clones following nuclear transfer with transfected and nontransfected fetal fibroblasts and in vitro - matured oocytes. Biol. Reprod. 64, 849-856

Kikyo N., Wolffe A.P., 2000. Reprogramming nuclei: insights from cloning, nuclear transfer and heterokaryons. J. Cell Sci. 113, 11-20

King M.P., Attardi G., 1988. Injection of mitochondria into human cells leads to a rapid replacement of the endogenous mitochondrial DNA. Cell 52, 811-819

King M.P., Attardi G., 1989. Human cells lacking mtDNA: repopulation with exogenous mitochondria by complementation. Science 246, 500-503

King T.C., Low R.L., 1987. Mapping of control elements in the displacement loop region of bovine mitochondrial DNA. J. Biol. Chem. 262, 6204-6213 
Kitiyanant Y., Saikhun J., Chaisalee B., White K.L., Pavasuthipaisit K., 2001. Somatic cell cloning in buffalo (Bubalus bubalis): effects of interspecies cytoplasmic recipients and activation procedures. Cloning Stem Cells 3, 97-104

Kono T., 1997. Nuclear transfer and reprogramming. Rev. Reprod. 2, 74-80

Kono T., Obata Y., Yoshimzu T., Nakahara T., Carroll J., 1996. Epigenetic modifications during oocyte growth correlates with extended parthenogenetic development in the mouse. Nat. Genet. 13, 91-94

Lacham-Kaplan O., Diamente M., Pushett D., Lewis I., Trounson A., 2000. Developmental competence of nuclear transfer cow oocytes after direct injection of fetal fibroblast nuclei. Cloning 2, 55-62

Lanza R.P., Cibelli J.B., Blackwell C., Cristofalo V.J., Francis M.K., Baerlocher G.M., Mak J., Schertzer M., Chavez E.A., Sawyer N., Lansdorp P.M., West M.D., 2000b. Extension of cell life-span and telomere length in animals cloned from senescent somatic cells. Science 288, 665-669

Lanza R.P., Cibelli J.B., Diaz F., Moraes C.T., Farin P.W., Farin C.E., Hammer C.J., West M.D., Damiani P., 2000a. Cloning of an endangered species (Bos gaurus) using interspecies nuclear transfer. Cloning 2, 79-90

Latham K.E., 1999. Epigenetic modification and imprinting of the mammalian genome during development. Curr. Top. Dev. Biol. 43, 1-49

Lee J., Inoue K., Ono R., Ogonuki N., Kohda T., Kaneko-Ishino T., Ogura A., Ishino F., 2003 a. Erasing genomic imprinting memory in mouse clone embryos produced from day 11.5 primordial germ cells. Development 129, 1807-1817

Lee J.H., Alberio R., Lloyd R.E., St. John J.C., Campbell K.H.S., 2003b. Development of ovine nuclear transfer embryos reconstructed using donor cells depleted of mitochondrial DNA (mtDNA). In: Proceedings of the $3^{\text {rd }}$ Joint Meeting of the Society for Reproduction and Fertility, University of Aberdeen (UK). Reproduction Abstr., Ser. 30, pp. 48-49

Lee J.-W., Wu S.-C., Tian X.C., Barber M., Hoagland T., Riesen J., Lee K.-H., Tu C.-F., Cheng W.T.K., Yang X., 2003c. Production of cloned pigs by whole-cell intracytoplasmic microinjection. Biol. Reprod. 69, 995-1001

Lloyd R.E., Bowles E.J., Alberio R., Lee J.H., Campbell K.H.S., St. John J.C., 2003. Analysis of levels of mitochondrial DNA (mtDNA) transcripts in donor cells for use in somatic cell nuclear transfer (SCNT). In: Proceedings of the $3^{\text {rd }}$ Joint Meeting of the Society for Reproduction and Fertility, University of Aberdeen (UK). Reproduction Abstr., Ser. 30, p. 49

Loi P., Clinton M., Barboni B., Fulka Jr. I., Cappai P., Feil R., Moor R.M., Ptak G., 2002. Nuclei from nonviable ovine somatic cells develop into lambs after nuclear transplantation. Biol. Reprod. 67, 126-132

Loi P., Ptak G., Barboni B., Fulka J.Jr., Cappai P., Clinton M., 2001. Genetic rescue of an endangered mammal by cross-species nuclear transfer using post-mortem somatic cells. Nature 19, 962-964

Mann M.R.W., Chung Y.G., Nolen L.D., Verona R.I., Latham K.E., Bartolomei M.S., 2003. Disruption of imprinted gene methylation and expression in cloned preimplantation stage mouse embryos. Biol. Reprod. 69, 902-914

Mannen H., Kojima T., Oyama K., Mukai F., Ishida T., Tsuji S., 1998. Effect of mitochondrial DNA variation on carcass traits of Japanese Black cattle. J. Anim. Sci. 76, 36-41

McCreath K.J., Howcroft J., Campbell K.H.S., Colman A., Schnieke A.E., Kind A.J., 2000. Production of gene targeted sheep by nuclear transfer from cultured somatic cells. Nature 405, 1066-1069

Meirelles F.V., Bordignon V., Watanabe Y., Watanabe M., Dayan A., Lobo R.B., Garcia J.M., Smith L.C., 2001. Complete replacement of the mitochondrial genotype in a Bos indicus calf reconstructed by nuclear transfer to a Bos taurus oocyte. Genetics 158, 351-356 
Meirelles F.V., Smith L.C., 1997. Mitochondrial genotype segregation in a mouse heteroplasmic lineage produced by embryonic karyoplast transplantation. Genetics 145, 445-451

Meirelles F.V., Smith L.C., 1998. Mitochondrial genotype segregation during preimplantation development in mouse heteroplasmic embryos. Genetics 148, 877-883

Michaels G.S., Hauswirth W.W., Laipis P.J., 1982. Mitochondrial DNA copy number in bovine oocytes and somatic cells. Develop. Biol. 94, 246-251

Nagao Y., Totsuka Y., Atomi Y., Kaneda H., Lindahl K.F., Imai H., Yonekawa H., 1998. Decreased physical performance of congenic mice with mismatch between the nuclear and the mitochondrial genome. Genes Genet. Syst. 73, 21-27

Nagao Y., Totsuka Y., Atomi Y., Kaneda H., Yonekawa H., Takahashi S., Imai H., 1997. Heterogeneous mitochondrial DNA introduced by nuclear transfer influences the developmental ability of mouse embryos in vitro. Theriogenology 47, 233 (Abstr.)

Nguyen B.X., Ty L.V., Chi B.L., Duc N.H., Uoc N.T., 2000. Comparison between the efficiencies of using domestic bovine and swamp buffalo oocytes as host ooplasts for embryo production by adult cell nuclear transfer. Theriogenology 53, 235 (Abstr.)

Niemann H., Wrenzycki C., Lucas-Hahn A., Brambrink T., Kues W.A., Carnwath J.W., 2002. Gene expression patterns in bovine in vitro-produced and nuclear transfer-derived embryos and their implications for early development. Cloning Stem Cells 4, 29-38

Park K.W., Lai L., Cheong H.T., Cabot R., Sun Q.Y., Wu G., Rucker E.B., Durtschi D., Bonk A., Samuel M., Rieke A., Day B.N., Murphy C.N., Carter D.B., Prather R.S., 2002. Mosaic gene expression in nuclear transfer-derived embryos and the production of cloned transgenic pigs from ear-derived fibroblasts. Biol. Reprod. 66, 1001-1005

Pessa-Morikawa T., Niku M., Iivanainen A., 2004. Persistent differences in the level of chimerism in B versus T cells of freemartin cattle. Develop. Comp. Immunol. 28, 77-87

Piko L., Taylor K.D., 1987. Amounts of mitochondrial DNA and abundance of some mitochondrial gene transcripts in early mouse embryos. Develop. Biol. 123, 364-374

Plante Y., Schmutz S.M., Lang K.D.M., 1992. Restriction fragment length polymorphism in the mitochondrial DNA of cloned cattle. Theriogenology 38, 897-904

Prather, R.S., 2000. Pigs is pigs. Science 289, 1886-1887

Reik W., Dean W., Walter J., 2001. Epigenetic reprogramming in mammalian development. Science 293, 1089-1093

Renard J.P., Zhou Q., LeBourhis D., Chavatte-Palmer P., Hue I., Heyman Y., Vignon X., 2002. Nuclear transfer technologies: between successes and doubts. Theriogenology 57, 203-222

Rideout III W.M., Eggan K., Jaenisch R., 2001. Nuclear cloning and epigenetic reprogramming of the genome. Science 293, 1093-1098

Roh S., Hwang W.-S., 2002. In vitro development of porcine parthenogenetic and cloned embryos: comparison of oocyte-activating techniques, various culture systems and nuclear transfer methods. Reprod. Fert. Develop. 14, 93-99

Ruddock N.T., Wilson K.J., Cooney M.A., Korfiatis N.A., Tecirlioglu R.T., French A.J., 2004. Analysis of imprinted messenger RNA expression during bovine preimplantation development. Biol. Reprod. 70, 1131-1135

Saikhun J., Pavasuthipaisit K., Jaruansuwan M., Kitiyanant Y., 2002. Xenonuclear transplantation of buffalo (Bubalus bubalis) fetal and adult somatic cell nuclei into bovine (Bos indicus) oocyte cytoplasm and their subsequent development. Theriogenology 57, 1829-1837

Samiec M., 2004. Development of pig cloning studies: past, present and future. J. Anim. Feed Sci. $13,211-238$

Santos F., Dean W., 2004. Epigenetic reprogramming during early development in mammals. Reproduction 127, 643-651 
Schutz M.M., Freeman A.E., Beitz D.C., Mayfield J.E., 1992. The importance of maternal lineage on milk yield traits of dairy cattle. J. Dairy Sci. 75, 1331-1341

Schutz M.M., Freeman A.E., Lindberg G.L., Koehler C.M., Beitz D.C., 1994. The effect of mitochondrial DNA on milk production and health of dairy cattle. Livest. Prod. Sci. 37, 283-295

Shi W., Dirim F., Wolf E., Zakhartchenko V., Haaf T., 2004. Methylation reprogramming and chromosomal aneuploidy in in vivo fertilized and cloned rabbit preimplantation embryos. Biol. Reprod. 71, 340-347

Shi W., Hoeflich A., Flaswinkel H., Stojkovic M., Wolf E., Zakhartchenko V., 2003b. Induction of a senescent-like phenotype does not confer the ability of bovine immortal cells to support the development of nuclear transfer embryos. Biol. Reprod. 69, 301-309

Shi W., Zakhartchenko V., Wolf E., 2003a. Epigenetic reprogramming in mammalian nuclear transfer. Differentiation 71, 91-113

Smith L.C., Bordignon V., Garcia J.M., Meirelles F.V., 2000. Mitochondrial genotype segregation and effects during mammalian development: applications to biotechnology. Theriogenology 53, $35-46$

Smith L.C., Murphy B.D., 2004. Genetic and epigenetic aspects of cloning and potential effects on offspring of cloned mammals. Cloning Stem Cells 6, 126-132

Starno J.M., Cummins J., Greeff J., Lymbery A.J., 2002. Mitochondrial DNA polymorphisms and fertility in beef cattle. Theriogenology 57, 1603-1610

Steinborn R., Schinogl P., Wells D.N., Bergthaler A., Muller M., Brem G., 2002. Coexistence of Bos taurus and $B$. indicus mitochondrial DNAs in nuclear transfer-derived somatic cattle clones. Genetics 162, 823-829

Steinborn R., Schinogl P., Zakhartchenko V., Achmann R., Schernthaner W., Stojkovic M., Wolf E., Muller M., Brem G., 2000. Mitochondrial DNA heteroplasmy in cloned cattle produced by fetal and adult cell cloning. Nat. Genet. 25, 255-257

Steinborn R., Zakhartchenko V., Jelyazkov J., Klein D., Wolf E., Muller M., Brem G., 1998a. Composition of parental mitochondrial DNA in cloned bovine embryos. FEBS Lett. 426, 352-356

Steinborn R., Zakhartchenko V., Wolf E., Muller M. Brem G., 1998b. Non-balanced mix of mitochondrial DNA in cloned cattle produced by cytoplast-blastomere fusion. FEBS Lett. 426, 357-361

St. John J.C., Lloyd R.E.I., Bowles E.J., Thomas E.C., Shourbagy S.El., 2004. The consequences of nuclear transfer for mammalian foetal development and offspring survival. A mitochondrial DNA perspective. Reproduction 127, 631-641

Stojkovic M., Machado S.A., Stojkovic P., Zakcharchenko V., Hutzler P., Goncalves P.B., Wolf E., 2001. Mitochondrial distribution and adenosine triphosphate content of bovine oocytes before and after in vitro maturation: correlation with morphological criteria and developmental capacity after in vitro fertilization and culture. Biol. Reprod. 64, 904-909

Surani A., 2001. Reprogramming of genome function through epigenetic inheritance. Nature 414, $122-128$

Takeda K., Akagi S., Kaneyama K., Kojima T., Takahashi S., Imai H., Yamanaka M., Onishi A., Hanada H., 2003. Proliferation of donor mitochondrial DNA in nuclear transfer calves (Bos taurus) derived from cumulus cells. Mol. Reprod. Dev. 64, 429-437

Takeda K., Takahashi S., Onishi A., Goto Y., Miyazawa A., Imai H., 1999. Dominant distribution of mitochondrial DNA from recipient oocytes in bovine embryos and offspring after nuclear transfer. J. Reprod. Fertil. 116, 253-259

Takeda K., Takahashi S., Onishi A., Hanada H., Imai H., 2000. Replicative advantage and tissuespecific segregation of RR mitochondrial DNA between C57BL/6 and RR heteroplasmic mice. Genetics $155,777-783$ 
Tian X.C., Xu J., Yang X., 2000. Normal telomere lengths found in cloned cattle. Nat. Genet. 26, $272-273$

Vignon X., Zhou Q., Renard J.P., 2002. Chromatin as a regulative architecture of the early developmental functions of mammalian embryos after fertilization or nuclear transfer. Cloning Stem Cells 4, 363-377

Wells D.N., Misica P.M., Tervit H.R., 1999. Production of cloned calves following nuclear transfer with cultured adult mural granulosa cells. Biol. Reprod. 60, 996-1005

White K.L., Bunch T.D., Mitalipov S., Reed W.A., 1999. Establishment of pregnancy after the transfer of nuclear transfer embryos produced from the fusion of argali (Ovis ammon) nuclei into domestic sheep (Ovis aries) enucleated oocytes. Cloning 1, 47-54

Wrenzycki C., Lucas-Hahn A., Herrmann D., Lemme E., Korsawe K., Niemann H., 2002. In vitro production and nuclear transfer affect dosage compensation of the X-linked gene transcripts G6PD, PGK, and Xist in preimplantation bovine embryos. Biol. Reprod. 66, 127-134

Yamazaki Y., Meirelles F.V., Bordignon V., Garcia J.M., Smith L.C., 1999. Effect of mitochondrial DNA on developmental outcome of cytoplast-reconstructed mouse zygotes. Arq. Fac. Vet. UFRGS 27, 299 (Abstr.)

Yang C.X., Han Z.M., Wen D.C., Sun Q.Y., Zhang K.Y., Zhang L.S., Wu Y.Q., Kou Z.H., Chen D.Y., 2003. In vitro development and mitochondrial fate of macaca-rabbit cloned embryos. Mol. Reprod. Dev. 65, 396-401

Yang C.-X., Kou Z.-H., Wang K., Jiang Y., Mao W.-W., Sun Q.-Y., Sheng H.-Z., Chen D.-Y., 2004. Quantitative analysis of mitochondrial DNAs in macaque embryos reprogrammed by rabbit oocytes. Reproduction 127, 201-205

Young L.E., Beaujean N., 2004. DNA methylation in the preimplantation embryo: the differing stories of the mouse and sheep. Anim. Reprod. Sci. 82-83, 61-78 


\section{STRESZCZENIE}

Wpływ genomu mitochondrialnego na strukturalne przemodelowanie i epigenetyczne
przeprogramowanie egzogennych jąder komórkowych w zarodkach klonalnych ssaków

Istnieje kilka gatunkowo specyficznych czynników epigenetycznych obecnych w cytoplazmie oocytu, które mogą prowadzić doniekompatybilnego wzorca interakcji jądrowo-cytoplazmatycznych, albo bezpośrednio po transplantacji jądra komórki-dawcy, bądź w późniejszych stadiach rozwoju zarodków klonalnych. $Z$ kolei, ten potencjalny brak koordynacji we wzajemnych oddziaływaniach czynników jądrowych i cytozolowych hybrydowych zygot klonalnych jest prawdopodobnie jednym z powodów ograniczonego potencjału praktycznych możliwości aplikacyjnych technologii klonowania somatycznego ssaków. Wykazano, że cząsteczki mtDNA pochodzenia matecznego, zakumulowane $\mathrm{w}$ mitochondrialnych rezerwuarach cytozolu oocytu-biorcy, odgrywają istotną rolę $\mathrm{w}$ asynchronicznym charakterze interakcji jądrowo-cytoplazmatycznych. Asynchronia ta obejmuje zarówno akompatybilne zmiany epigenetycznych modyfikacji somatycznego genomu dawcy, kierującego programem rozwojowym zrekonstytuowanej cybrydy klonalnej, jak i brak synergistycznego przebiegu molekularnych mechanizmów regulatorowych, zaangażowanych w punkty restrykcyjne kariokinezy i cytokinezy, które są odpowiedzialne za skoordynowane przejście z pseudomejotycznej do mitotycznej kontroli cyklu komórkowego po sztucznej aktywacji rekonstytuowanego oocytu. Ponadto udowodniono, że obecność mitochondrialnego aparatu genetycznego pochodzenia oocytarnego wpływa także na proces implantacji zarodków klonalnych w endometrium macicy samic-biorczyń (matek zastępczych). $\mathrm{Z}$ tego też względu, w przypadku występowania zjawiska mitochondrialnej heteroplazmii komórkowej w rekonstruowanych hybrydachjądrowo-cytoplazmatycznych, nie można wykluczyć niekorzystnego efektu oddziaływania heterogenicznych źródeł mtDNA na przedimplantacyjny rozwój zarodków klonalnych. Dlatego też uzyskiwanie zarodków, płodów i potomstwa klonalnego z dokładnie określonymi konstelacjami poszczególnych sekwencji nukleotydowych w odcinkach regulatorowych lub kodujących genomu jądrowego i/lub mitochondrialnego może mieć niezwykle istotne znaczenie w doświadczeniach nad rozdziałem efektów oddziaływania genetycznych i/lub epigenetycznych komponentów jądrowych i cytoplazmatycznych, jak również wewnątrzmacicznego środowiska pseudociężarnych samicbiorczyń na rozwój zarodkowy, płodowy oraz postnatalny osobników klonalnych. 